\title{
Højskolen og Grundtvig
}

\section{Af Søren Jensen}

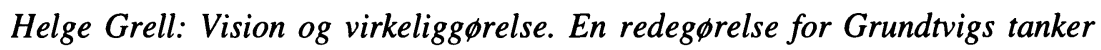
om folkelig oplysning og en folkelig højskole og for forsфget på at virkeliggøre dem. Center for Grundtvig-Studier, Aarhus Universitet, $i$ kommission hos Aarhus Universtitetsforlag. Århus 1998, 154 s. Kr. 150.

Bagateller, som f. eks. bemærkninger til korrekturen, er det rimeligst at komme med i slutningen af en anmeldelse, men jeg vil gøre en undtagelse og begynder med et surt opstød. Ved læsningen af Helge Grells nyeste bog om Grundtvig og højskolebevægelsen har jeg nemlig noteret mere end 800 trykfejl og korrektioner, og så garanterer jeg for, at jeg ikke har fundet alle fejl. F. eks. har jeg ikke eftergået alle citater, men når et otteliniers citat (s. 11) har 17 rettelser, og vel at mærke ikke kun komma- og stavefejl, også ord, der mangler, eller ord, der er tilsat citatet, eller når et andet otteliniers citat (s. 74) har 10 af samme slags foruden en forkert henvisning, så vil der uden al tvivl være mere at korrigere, hvis man går teksten efter i sømmene. Men ærligt talt er det ikke læserens opgave at læse korrektur. Det er forfatterens og forlæggerens. Den moderne tekstbehandlingsteknik forleder til at tro, at teksten er trykklar, når den er skrevet. Det er den sjældent. Det sædvanlige korrektionsarbejde forestår og må ikke glemmes. Det har virkelig været anstrengende at læse Grells bog, en anstrengelse, som først skal overkommes, før man når ned til det saglige. Hvis man når så langt, er der til gengæld meget at blive klog på, men de mange trykfejl har - i hvert fald i mit tilfælde - været til stor irritation og gjort læsningen uforholdsmæssig besværlig.

Men så til sagen - og lad mig med det samme sige, at jeg anlægger én af flere mulige vinkler på Helge Grells bog. Jeg går med andre ord ikke i detaljer med fremstillingen.

Alle ved, at de tanker om en højskole, som Grundtvig anskueliggjorde med 'skolen i Soer', aldrig blev realiseret. Begrænser man derfor hans ideer om højskole og folkelig oplysning til kun at handle om 'skolen i Soer', er det indlysende, at der ingen forbindelse kan være mellem Grundtvig og højskolebevægelsen. Men så kantet er der heller ingen, der tænker eller har tænkt. Den virkeliggjorte højskole var fra begyndelse et blandingsfænomen, et ganske legitimt blandingsfænomen.

Ser man på de første år af den realiserede højskoles tid, kunne man ellers godt argumentere for den modsatte opfattelse. Grundtvig skænkede nemlig ikke Rødding Højskole nogen særlig interesse, for i midten af 1840rne havde han endnu en forhåbning om, at 'skolen i Soer' ville blive til noget. Men som tiden gik, måtte han ændre syn. »I perioden fra 1834 til treårskrigens begyndelse er Grundtvigs tale om folkelig oplysning og en folkelig højskole og 
om skolen i Sorø af ganske entydig karakter« (s. 47). Med tiden lærte han altså at skelne, vel ikke fordi han brød sig om det, men fordi omstændighederne gjorde det nødvendigt. Der må derfor spørges dybere, spørges til Grundtvigs "menneske- og historiesyn«, for nu at bruge den formel, med hvilken Grell lidt stereotypt og tit sammenfatter Grundtvigs tilværelsesforståelse.

Denne tilværelsesforståelse, som også ligger bag oplysningsprogrammet, har Grell sat sig for at karakterisere ud fra en lang række grundtvigtekster både prosa og poesi - og at efterspore hos dem, han med et problematisk udtryk kalder første generation af grundtviginspirerede højskoleledere, for at vurdere, om det nu virkelig er den, der blev realiseret i højskolebevægelsen i sidste halvdel af det 19. århundrede.

I bogens andet hovedkapitel fremlægges så højskolesynet hos fem udvalgte højskoleforstandere: Kold, Schrøder, Trier, Jens Nørregaard og nordmanden Christoffer Bruun, for at vurdere deres forhold til Grundtvigs højskolesyn.

Endelig lader Grell i det sidste kapitel nogle af de samtidige kritikere af højskolen komme til orde for gennem deres kritik yderligere at kaste lys over forholdet mellem Grundtvigs vision og dens virkeliggørelse.

Der er grund til at være lidt skeptisk med hensyn til vigtigheden af denne problemstilling. Jeg siger ikke, at den er uvæsentlig, naturligvis ikke, men vi har at gøre med et historisk forløb, hvor lokale behov lige fra højskolens start har blandet sig med inspirationen fra Grundtvig. Det er der ingen med blot en smule kendskab til højskolens historie, der er i tvivl om. Men det betød så, at de initiativer, der blev taget, afstedkom en realisering, der ikke altid direkte refererede til Grundtvigs ideer, og det var altså helt legitimt. I denne forbindelse skal det ikke glemmes, at højskolens historie - set i det store perspektiv - blev en succeshistorie. Grells problemstilling er altså nok vigtig, men spørgsmålet må siges at komme i anden række.

Når man gør forholdet mellem vision og virkeliggørelse til sit emne, er det vigtigt at se, hvorledes den første generation af højskolefolk etablerede sig. Det påstår Grell også, at han gør, men han begynder nu ikke ved begyndelsen. Der er ingen tvivl om, at den måde, hvorpå Rødding Højskole realiseredes, blev til inspiration for de senere højskolefolk. Man må derfor prøve at besvare spørgsmålet: Hvilken betydning har det haft, at Rødding Højskole som den første fra begyndelsen blev etableret ud fra lokale behov, der ikke i ét og alt var i overensstemmelse med Grundtvigs tanker om (Sorø) højskolen? Og i forlængelse heraf må man tage i betragtning, at Rødding Højskole - alt andet lige - på disse præmisser udviklede sig på tilfredsstillende vis. Dette spørgsmål berøres overhovedet ikke i Grells bog. Det må dog være vigtigt, hvis man vil unders $\emptyset$ ge og vurdere forholdet mellem Grundtvigs oprindelige højskolesyn og den højskolevirksomhed, der udfoldede sig i sidste halvdel af forrige århundrede. Jeg tror, at inspirationen fra Chr. Flor til at etablere højskole primært ud fra de lokale behov og så i øvrigt lade sig inspirere af Grundtvig i det omfang, ressourcerne og mulighederne var til stede, har haft betydning for den almindelige højskolebevægelse. Der er i øvrigt historisk belæg for, at Grundtvig selv 
nikkede anerkendende til en sådan praksis - altså på trods af den manglende overensstemmelse mellem denne praksis og det oprindelige syn.

I det hele taget er det, som om Grell ganske overser Rødding og de af skolens forstandere, som ytrede sig om den nye form for skolevirksomhed. Vi hører intet om, hvad Flor, Frederik Helveg eller Sofus Høgsbro ytrede om det forhold, der udgør Grells grundlæggende problemstilling. Og disse herrer hører jo i højere grad end de udvalgte til 'den første generation'. Ludvig Schrøder, der var forstander på Rødding i 3 år, hører vi om, men det er især efter 1865, da han fortsatte sin virksomhed i Askov.

En bog som den foreliggende kan naturligvis ikke være dækkende. Den må nødvendigvis være selektiv i valget af eksempler. Det er Grell helt på det rene med, men når det er formålet at 'afsløre' diskrepansen til højskoleideens virkeliggørelse, er det nødvendigt at tage den historiske udvikling med, så rimeligheden af den løse forbindelse til idegrundlaget bliver belyst.

Bogen er ikke for nybegyndere. Der er med andre ord ikke tale om en introduktion hverken til baggrunden for eller til realiseringen af Grundtvigs idé om højskolen. Ikke fordi man ikke får indsigt i de to områder, men de tekster, der analyseres, er i høj grad andre end de sædvanlige. Det er for så vidt forfriskende, men det forudsætter, at læseren kender de klassiske. Endnu én forudsætning er det godt at have. Skal man have fuldt udbytte af denne bog, skal man helst kende den Grundtvig-tolkning, som Grell med stor indlevelse har givet, især i disputatsbøgerne.

Delvis til støtte for sine synspunkter refererer Grell den kritik af højskolen, som kommer til udtryk i nogle af Otto Møllers, Morten Pontoppidans og Jakob Knudsens afhandlinger og artikler. Det er meget spændende at læse, men man skal naturligvis se den slags kritiske indlæg i forhold til de samtids- og situationsbestemte omstændigheder, hvorunder de fremkom. Det synes jeg, Grell forsømmer lidt, og han er derfor på nippet til at overtolke dem.

Generelt må man sige, at referater eller resuméer af bøger og artikler fremstår i en ret mekanisk form, og sproget er fyldt med akademiske floskler og sætningskonstruktioner, der mest af alt minder om $\emptyset$ velsesopgaver og specialer. F. eks. den fire liniers lange kapiteloverskrift på side 11: »Baggrund og forudsætninger for Grundtvigs tanker om folkelig oplysning og en folkelig $h ø j-$ skole«. Det er en både grim og alt for lang overskrift. Men derudover bærer selve teksten vidnesbyrd om, at en sproglig revision (ud over korrekturlæsningen) ville have været til gavn.

Vision og virkeliggørelse, som jeg antager, bogen hedder (man kan nemlig godt komme i tvivl, for på bogens ryg står en anden titel: Vision og realisering af Grundtvig - men hvad det skulle betyde, tør jeg slet ikke tænke på, så jeg holder mig til titelbladets titel), skal trods alt roses, fordi den fremlægger $\mathrm{og}$ fortolker en række tekster, som man ikke møder så tit. Men med den synsvinkel, jeg har anlagt, kan man ikke sige, at bogen bidrager med noget egentlig nyt. 